\title{
Pozitivní podpora chování (PBIS) jako nástroj pro komplexní péči o duševní zdraví žákự
}

\section{PBIS as a Tool For Comprehensive Mental Health Support in Pupils}

\author{
Anna Kubíčková ${ }^{2}$ ČOSIV, PedF UK, Praha \\ Lenka Felcmanová, ČOSIV, PedF UK, Praha
}

\begin{abstract}
Abstrakt
Mnoho dětí je vystaveno výrazně negativním zkušenostem, které ovlivňují jejich chování, duševní i fyzické zdraví a budoucí život. Text příspěvku nastiňuje ty to okolnosti a nabízí řešení ve formě plošné podpory duševního zdraví dětí a mladých lidí pomocí zavedení celoškolního trauma respektujícího př́istupu. Prostřednictvím implementačního rámce PBIS mohou školy flexibilně reagovat na potřeby a projevy žákủ v rámci tř́ úrovní podpory jejich chování. Výzkumné šetření ověřovalo, v jaké fázi zavedení I. úrovně rámce PBIS se nacházejí tři pilotní školy po zahájení projektu a úvodním proškolení pedagogického sboru. Ověřený nástroj Benchmarks of Quality využívaný k evaluaci přesnosti (tzv. fidelity) implementace PBIS poukázal na to, že I. úroveň podpory nebyla na pilotních školách zatím plnězavedena.
\end{abstract}

\section{Klíčová slova}

trauma respektující přístup, pozitivní podpora chování, negativní zkušenosti v dětstuí, duševní zdraví, PBIS,

\section{Abstract}

Many children are exposed to significantly adverse experiences that affect their behavior, mental and physical health, and future life. The following text outlines these circumstances and offers a solution in the form of comprehensive support of children mental health through the introduction of a school-wide trauma informed approach. With the PBIS implementation framework, schools can respond flexibly to pupils' needs and behaviors within three tiers of behavioral support. The research survey evaluated the first-tier implementation stage of the three pilot schools after their enrolment in the project and the initial training of the school faculty. The validated tool Benchmarks of Quality used to measure fidelity od PBSI implementation uncovered that the first level of support has not yet been fully implemented in pilot schools.

\section{Keywords}

Trauma Informed Approach, Positive Behavioral Interventions and Supports, Adverse Childhood Experiences, Mental Health, PBIS

\section{Úvod}

Základní škola je pro některé děti místem vzdělávání a socializace, pro jiné může být útočištěm a jediným skutečně bezpečným prostředím. Pro některé děti se může také stát dalším místem, kde zažívají neúspěch v chování a sociálních interakcích, kde jsou často vnímány jako rušivý prvek a kde jsou nabádány k soustředění na učební látku, přestože je jejich aktuální nebo dlouhodobá životní situace naléhavější než vyhlídka dobrých vzdělávacích výsledků. Zavedení víceúrovňového trauma respektujícího přístupu, jehož příkladem je Pozitivní podpora chování PBIS pomáhá školám odhalit faktory ovlivňující chování dětí, preventivně předcházet méně závažným projevům nevhodného chování všech dětí a poskytnout efektivní

1 Rešerše přístupů podpory duševního zdraví žáků a výzkum dopadů implementace Pozitivní podpory chování byl podpořen Grantovou agenturou Univerzity Karlovy (projekt č. 1034419)

2 Kontaktní osoba: anna.kubickova@cosiv.cz 
podporu i dětem v náročných situacích a s komplexními potřebami v oblasti chování a duševního zdraví. Text př́ispěvku poukazuje na nutnost zavedení dlouhodobé plošné podpory duševního zdraví dětí a ukazuje na příkladu tří pilotních škol, jak lze započít zavádění celoškolního trauma respektujícího přístupu s pomocí implementačního rámce PBIS.

\section{Současný stav poznání}

Podpora duševního zdraví dětí a mladistvých (dále jen dětí) je dlouhodobým tématem ve výzkumu i v praxi, a to v širokém spektru pohledů, od sociologického, přes psychologický a pedagogický až k tomu ekonomickému. Velký zlom v uvažování o podpoře duševního zdraví však přinesla takzvaná ACE Study, která již v 90. letech minulého století prokázala na vzorku 8056 respondentů nejen dlouhodobé závažné dopady takzvaných negativních zkušeností v dětství (dále také NZD)³ na fyzické zdraví jedince, ale také znepokojivě vysokou prevalenci těchto potenciálně traumatizujících zkušeností v populaci. Kromě výrazně negativního vlivu na chování a fyzické zdraví jedince jsou NZD spojovány také s obtížemi v oblasti psychiky a duševního zdraví. U osob, které deklarovaly negativní zkušenosti v dětství ze 4 a více kategorií (například kombinace fyzického násilí, uživání návykových látek v rodině, násilí na matce a kriminálního chování členů domácnosti), byl prokázán 4,6krát vyšší výskyt depresivních stavư ${ }^{4}$ a 12,2krát vyšší výskyt pokusu o sebevraždu oproti skupině osob, jež nedeklarovala žádnou z kategorií NZD. U osob se dvěma různými kategoriemi negativních zkušeností pak byl výskyt depresivních stavo̊ 2,6krát vyšší a pokusy o sebevraždu 3krát častějš́í.

Z pohledu prevalence negativních zkušeností v dětství se v populaci pouze 49,5 \% jedinců nesetkalo s žádnou ze sledovaných kategorií NZD, 24,9 \% s jednou kategorií, 12,5\% se dvěma, 6,9 \% se třemi a 6,2 \% se čtyřmi a více kategoriemi (Felitti et al., 1998). Nedávná studie negativních zkušeností v dětství Světové zdravotnické organizace provedená na populaci českých studentů vysokých škol dokládá, že z jedenácti sledovaných kategorií ${ }^{5}$ NZD se pouze 37,8 \% studentů nesetkalo z žádnou ze sledovaných negativních zkušeností, 24,9 \% uvedlo jednu kategorii, 27,4 \% uvedlo NZD ze dvou až tří kategorií a 9,9 \% studentů mělo negativní zkušenosti v dětství ze čtyř a více sledovaných kategorií (Velemínský et al., 2017).

Vzhledem k zastoupení pouze vysokoškolských studentů lze uvažovat, že v české populaci bude prevalence NZD vyšší, než uvádí studie WHO. Dále je nutné zohlednit, že studie nezahrnují další kategorie negativních zkušeností, jež mají potenciál také výrazně negativně ovlivňovat chování a prožívání jedince, jako je například emoční zanedbávání, násilí v komunitě, náhradní rodinná péče, šikana, rasismus a narušené sousedské bezpečí (Cronholm et al., 2015). Zahrnuty nebyly ani přírodní nebo člověkem způsobené katastrofy, chudoba, smrt blízké osoby, válka, terorismus, politické násilí apod., jakožto situace vyvolávající chronický stres a které jsou potenciálně traumatizující (Gerrity \& Folcarelli, 2008). Dalším negativním vlivem, který může působit souběžně s negativními zkušenostmi je znevýhodňující sociální prostředí, ve kterém dítě žije (např. v sociálně vyloučené lokalitě). Tento negativní vliv zasahuje do zdrojů dítěte a rodiny při snižování následků negativních zkušeností. Působení vzájemně se ovlivňujících NZD a dalších forem negativních sociálních vlivů výrazně ovlivňuje psychický vývoj dítěte (Nurius, Logan-Greene, \& Green, 2012).

Takto vysoká prevalence NZD v populaci musí být adresována již na úrovni primární prevence psychických obtíži mířené dlouhodobě na všechny děti. Individuálními nebo skupinové intervence s dostatečnou frekvencí a potřebným dlouhodobým působením by měly plošné působení doplňovat, nikoliv nahrazovat. Bez systémových opatření hrozí riziko, že některé děti vystavené negativním zkušenostem s dopadem na jejich vývoj zůstanou systémem nerozpoznány. Je tedy vhodné zavádět přístupy, jež pomáhají dlouhodobě působit na širokou populaci dětí s diferencovanou mírou podpory. Z tohoto pohledu se jeví jako nejvhodnější zavedení celoškolního víceúrovňového trauma respektujícího přístupu. Příkladem takové-

3 Negativní zkušenosti v dětství (anglicky Adverse Childhood Experiences neboli ACEs) byly v původní studii rozděleny do sedmi kategorií nevhodného zacházení a dysfunkčního rodinného prostředí - psychické týraní, fyzické týraní, sexuální zneužívání, užívání návykových látek v rodině, duševní onemocnění v rodině, násilí vǔči matce, kriminální chování členů domácnosti (Felitti et al., 1998).

4 Dva a více týdnů depresivních nálad v průběhu posledního roku

5 Psychické týraní, fyzické týraní, sexuální zneužívání, fyzické zanedbávání, uživání návykových látek v rodině, alkoholismus v rodině, duševní onemocnění v rodině, pokus o sebevraždu v rodině, domácí násilí, kriminální chování členů domácnosti, rozvod nebo separace rodičůu (Velemínský et al., 2017). 
ho přístupu je např. implementační rámec celoškolní Pozitivní podpory chování PBIS (Zakszeski et al., 2017).

Vzhledem k tomu, že naprostá většina dětí byla a je vzdělávána v základních školách (Brant, Nováková \& Tupý, 2004), kde tráví v průběhu devíti let povinného vzdělávání přes 7000 hodin v přímé výuce (OECD, 2018) a další velký objem času o přestávkách a mimo vyučování, můžeme konstatovat, že základní škola má zásadní vliv na vývoj dětí a jejich život jako takový. Dítě se v průběhu vzdělávání setká s různými pedagogy, kteří svým působením jako střípky v mozaice utvářejí celkový dopad povinné školní docházky na jeho život. Uvažujme, s jakým přístupem ke své osobě, svému chování a vzdělávání se bude na základní škole setkávat hypotetická dívka A ze stabilního prostředí, která prozatím nemá negativní zkušenosti z žádné z výše popsaných kategorií oproti hypotetickému chlapci B, který vyrůstá s psychicky vyčerpanou matkou samoživitelkou a v předškolním a raném školním věku se setkával ze strany otce s fyzickým napadáním matky a sourozence. Z uvedeného popisu je zjevné, že by se chlapec B měl setkávat především s podporou pedagogů (a dalších významných dospělých), kteří by měli modelovat pečující vztah a respektující komunikaci, rozvíjet socio-emoční dovednosti a učit vhodnému řešení problémů. U chlapce B je však pravděpodobné, že se vlivem působení toxického stresu a negativních zkušeností proměnila vývojová struktura a fungování jeho mozku (Larkin, Shields \& Anda, 2012; Merrick, Ford, Ports \& Guinn, 2017) a kromě souvisejících vzdělávacích obtíží a projevů náročného chování7 (Sciaraffa, Zeanah \& Zeanah, 2018) má chlapec B také zcitlivělý systém reakce na stres. To se v jeho chování bude projevovat nepřiměřenými obrannými reakcemi na podněty, které by běžně aktivaci stresové reakce u dětí nevyvolaly či intenzivnější nebo delšś reakcí na mírné stresové podněty (Perry et al., 1995). Chlapec B, který nemá diagnostikováno ADHD ani poruchy chování by tedy byl pravděpodobně ve škole vnímán jako "náročnější“ či přímo „zlobivýu“ a oproti dívce A se bude nejspíše setkávat více s tresty a negativní zpětnou vazbou ze strany pedagogů. Zcitlivělý systém reakce na stres chlapce B však vyhodnotí rozzlobení pedagoga jako ohrožující situaci, což naruší pocit bezpečí ve škole a sounáležitosti ke školní komunitě. K tomu, aby měla škola možnost vhodně působit na všechny děti, včetně dětí s nerozpoznanými negativními zkušenostmi, musí změnit svůj přístup k chování a proživání dětí a začít uplatňovat tzv. trauma respektující přístup. Jednou z hlavních zásad tohoto př́stupu je zjištování přičin náročného chování a snaha předcházet nevhodným projevům $\mathrm{v}$ chování pomocí naplňování potřeb dětí (Davis, 2019; Honsinger \& Brown, 2019; Rawson 2020).

Podle principů trauma respektujícího přístupu by se měly děti, které jsou ovlivněny negativními zkušenostmi vzdělávat v prostředí, ve kterém je usilováno o naplňování jejich potřeb, a to především potřeb pocitu bezpečí, přijetí dětmi i dospělými a získávání dovedností v oblasti seberegulace. Školní kultura, a především pozitivní klima školy tak hraje klíčovou roli v podpoře vzdělávání dětí s negativními zkušenostmi, ale také pozitivně ovlivňuje vzdělávací výsledky všech žáků školy (Jones, Berg \& Osher, 2018). Trauma respektující přístup na školách obnáší především porozuměním dopadům negativních zkušeností v dětství a traumatu na chování, vzdělávání a duševní zdraví dětí a zajišstění naplňování tělesného, sociálního, emocionálního a akademického bezpečí, nastavení kulturně citlivých a pozitivních celoškolních pravidel chování, vytváření příležitostí k rozvoji nových dovedností, posilování soudržnosti školní komunity a v prípadě potřeby také zabezpečení přístupu ke komplexní péči v oblasti duševního zdraví a chování (Cole, 2013).

Implementační rámec Pozitivní podpory chování (dále PBIS ${ }^{8}$ je tř̌iúrovňový, celoškolní, trauma respektující přístup. Rámec PBIS vznikl koncem 80. let 20. století v USA, kde v současné době implementuje PBIS přes 26000 škol (Horner \& Macaya, 2018). Mimo USA je PBIS implementováno např́klad v Kanadě, Evropě, Asii, Austrálii, Africe či na Novém Zélandu (Colvin \& Sugai, 2018). Implementace PBIS pomáhá z části předcházet nevhodnému chování a poskytuje efektivní strategie podpory žáků, jejichž nevhodnému chování se nedaří předcházet. Školou poskytovaná podpora chování je tedy efektivnějš́i a zmenšuje podíl času, který by byl jinak věnován řešení obtíží nebo kázeňských přestupkủ ve výuce. Žákům navíc méně konfliktní a strukturované (neboli předvídatelné) prostředí přináší větší pocit bezpečí

6 Především se jedná o zvýšené riziko v oblasti deficitů pozornosti, jazykových deficitů, obtíží s řešením problémů, obtíží v nabývání nových dovedností a informací a obtíží s uvažováním v následných krocích (Sciaraffa, Zeanah \& Zeanah, 2018)

7 Riziko obtíží v seberegulaci, zvýšení impulzivity, opozičního a nestabilního chování, extrémních reakcí, odmítání, agrese, sebepoškozování, užívání návykových látek, útěků, prostituce a dalšíi (Sciaraffa, Zeanah \& Zeanah, 2018). 8 V USA známý pod názvem Positive Behavior Interventions \& Supports (PBIS), v Evropě především jako Positive Behaviour Support (PBS). 
a umožňuje tudíž lepší soustředění na učivo. PBIS tedy podporuje i zlepšování vzdělávacích výsledků žáků a zlepšuje školní klima. V neposlední řadě PBIS snižuje psychickou zátěž pedagogů a zvyšuje jejich celkovou spokojenost (Bradshaw et al., 2008; Clunies-Ross, Little \& Kienhuis, 2008; Horner et al., 2017; Keating, 2016).

Rámec PBIS je založen na čtyřech hlavních principech (Simonsen \& Sugai, 2013):

- Výsledky a cíle jsou nastaveny relevantně pro danou školu - cíle by měly být měřitelné, střednědobé i dlouhodobé, jejich dosahování je pravidelně sledováno a př́ípadně se upravují postupy nebo i cíle samotné.

- Data a jejich analýza jsou zohledňovány při rozhodování - sleduje se například docházka, počet poznámek, vzdělávací výsledky, ale i problematické prostory školy (např. chodba/jídelna), na základě analýzy dat je vyhodnocována účinnost jednotlivých intervencí ve vztahu k jednotlivým žákům i žákovskému kolektivu jako celku.

- Systémy podporující pedagogické pracovníky - vzdělávání pracovníků v problematice managementu chování a prvcích PBIS, vzájemné intervize, sdílení dobré praxe v rámci i mimo školu, odborné konzultace, podpora pedagogického sboru, ocenění dosažených úspěchů.

- Postupy podpory chování všech žáků a ověřené intervence - zavedení univerzální prevence nevhodného chování všemi pedagogy (I. úroveň), systém zvýšené podpory cílené na některé žáky (II. úroveň) a intenzivních individuálních intervencí pro žáky s komplexními potřebami (III. úroveň).

Hlavní principy jsou poměrně flexibilní a je tedy pravděpodobné, že budou mít školy různě nastavené cíle podle toho, v jaké lokalitě se nacházejí a v jaké oblasti identifikují nutnost zlepšení. Postupy, kterými mohou pedagogové pod porovat žáky, nejsou pevně dané, ale rámec PBIS obsahuje návodné a srozumitelné intervence a postupy, jež jsou ověřeny výzkumem a v praxi (dále evidence-based). Tyto postupy se poté rozčlení do pevné struktury tří úrovní podpory, jež je popsána níže. Škola může v tříúrovňové struktuře využít i jiné evidence-based postupy a intervence podporující chování žáků. PBIS může tedy na každé škole ale i v jednotlivých státech vypadat různě (Horner et. al., 2017; Nelen et al., 2020).

Implementace PBIS má několik fází a typicky se postupuje formou implementace každé ze tří úrovní v jednom školním roce. Tedy v prvním roce bude implementována I. úroveň podpory spočívající v zavedení nespecifické prevence zaměřené na podporu očekávaného chování a základních principů trauma respektujícího př́istupu ke všem žákům. V druhém roce je postupně zavedena II. úroveň podpory určená především žákům s opakujícími se mírnými obtížemi v oblasti chování a psychické pohody. Jedná se o několik vybraných intervencí, které efektivně využívají čas pedagogů tak, aby bylo možné podpořit žáky ohrožené rizikovým chováním v internalizované i externalizované podobě a snížil se podíl žáků vyžadujících individualizovanou multidisciplinární podporu. Ve třetím roce je implementována III. úroveň podpory, která vyžaduje koordinovanou multidisciplinární spolupráci a poskytuje individualizovanou podporu žákům s komplexními potřebami v oblasti chování a duševního zdraví (Bradshaw, 2013; Eber et al., 2020; Latham, 1998). Pedagogové zajištúující fungování intervencí II. a III. úrovně podpory by měli mít dostatečné znalosti o dopadech traumatu na chování, prožívání a vzdělávání dětí, současně s efektivními strategiemi podpory dětí ovlivněných negativními zkušenostmi (Eber et al., 2020).

Tři úrovně podpory při plné implementaci PBIS odpovídají uplatnění konceptu Reakce na intervenci ${ }^{9}$ a umožňují pedagogům flexibilně a efektivně poskytovat podporu žákům podle jejich aktuálních potřeb. I. úroveň podpory by měla mířit na všechny žáky školy s tím, že u 80-90 \% žákủ bude dostačující k tomu, aby předcházela opakujícím se obtížím v chování a podpořila celkový wellbeing žáků. Zhruba 5-15 \% žákủ školy bude potřebovat intenzivnější podporu II úrovně, ve které pedagogové poskytují více pozornosti vhodnému chování dítěte, zvyšují zpětnou vazbu na chování a strukturu prostředí a díky odhadu funkce chování a potřeb dítěte mohou lépe předcházet některým formám nevhodného chování. Přibližně 1-5 \% žáků školy bude vzhledem ke komplexním potřebám potřebovat individualizovaný týmový přístup III. úrovně ve spolupráci s relevantními odborníky a se zapojením samotného dítěte a/nebo jeho rodiny. Intervence třetí úrovně musí respektovat kulturní a sociální zázemí stejně tak jako negativní zkušenosti žáka, jež mohou jeho chování a proživání ovlivňovat (Bradshaw et al., 2008, Response To Intervention, 2013).

9 Reakce na intervenci, anglicky Response to Intervention (RtI) je metoda využívaná k identifikaci studentů s potřebou vyšší úrovně intervence jak v oblasti akademické, tak i v dalších oblastech, mezi něž patří především problémové chování či podpora duševního zdraví žákio (Response To Intervention, 2013). 


\section{Metoda}

Pozitivní podpora chování PBIS je v České republice pilotně implementována na třech základních školách díky projektu Škola pomáhá ohroženým dětem vedeném organizací Česká odborná společnost pro inkluzivní uzdělávání (ČOSIV). Projekt je realizován od března roku 2020 a je zaměřen především na podporu dětí ohrožených negativními zážitky a dětí vyrůstající ve ztížených podmínkách (COSIV, 2020). V rámci projektu byly školám poskytnuty vytvořené a přeložené materiály současně s proškolením pedagogického sboru v problematice negativních zkušeností v dětství, jejich dopadu na vzdělávání, příčin nevhodného chování, principech PBIS a postupech implementace I. úrovně PBIS. Zároveň byl sestaven tzv. školní PBIS tým, tvořený vedením školy nebo zástupcem, a pedagogy se zájmem o vzdělávání v oblasti náročného chování. V průběhu implementace PBIS budou školám dále dodávány materiály a informace včetně možností konzultace a v každém roce proběhne proškolení části pedagogického sboru v postupu implementace navazujících úrovní (ČOSIV, 2021).

Po proškolení pedagogického sboru a školního PBIS týmu každé ze tří pilotních škol byl administrován nástroj Benchmarks of Quality (dále BoQ) s ověřenou reliabilitou a validitou na vzorku 150 škol v USA (Cohen, Kincaid \& Childs, 2007). BoQ měří deset klíčových kritérií implementace I. úrovně PBIS na základní škole a je využíván při zavádění PBIS v zahraničí, a to především u nově implementujících škol, vzhledem k detailnímu popisu jednotlivých kritérií i relevantních důkazů o jejich naplňování. Pro sběr dat byl zvolen výběr vzorku na základě dostupnosti, kdy se jednalo o jediné tři školy v projektu pilotního zavádění PBIS v České republice.

\section{Výsledky}

Velikost zapojených škol podle počtu žáků ve školním roce 2020/21 obsahovala na ZŠ 1 a 3 přes $\mathbf{5 5 0}$ žáků a na ZŠ 2 přes 150 žáků. Administraci evaluačního nástroje Benchmarks of Quality (BoQ) prováděl školní PBIS tým (4 pedagogové na každé ze tří škol, kteří koordinují implementaci rámce) ve spolupráci s tzv. PBIS koučem, tedy odborníkem proškoleným v zavádění PBIS na základních školách, který současně na pilotních školách zajištuje školení pedagogického sboru a poskytuje konzultace v souvislosti s implementací PBIS.

Podle očekávání pilotní školy hodnotily úspěšnost v zavedení školního PBIS týmu nad 60 \% v každé ze škol a v průměru všech tři škol nad 70 \%. Ustavení školního PBIS týmu je podmínkou zavádění PBIS ve škole, konkrétně fáze př́pravné a zahajovací (Bradshaw et al., 2009) a bylo předmětem jednání se školami při zahájení projektu na konci školního roku 2019/20. Další kritérium, které bylo školami vysoce hodnoceno, bylo stanovení očekávaného chování s úspěšností v průměru 60 \%. Definování a praktický nácvik celoškolních pozitivně formulovaných očekávání v chování je jedním z hlavních principů PBIS a je součástí fáze zahajovací a implementační (Bradshaw et al., 2009). Dvě kritéria hodnocená školami v průměru nad 30 \%, tedy angažovanost pedagogického sboru a zavedené třídní systémy ${ }^{10}$, jsou důležitou součástí fungování PBIS a pilotní školy budou nadále podporovány ve zvyšování úspěšnosti plnění obou kritérií. Další kritéria hodnocená školami pod 30 \% byla diskutována se školním PBIS týmem a v průběhu školního roku byla vyvinuta snaha zvýšit úspěšnost v dosahování těchto kritérií.

Vzhledem k netradičnímu průběhu školního roku 2020/21 byla implementace I. úrovně PBIS naplněna jen částečně a projekt počítá s podporou implementace I. úrovně na všech pilotních školách i ve školním roce $2021 / 22$ a případně také 2022/23 současně při zavádění II. a následně III. úrovně podpory. U I. úrovně PBIS se tedy bude jednat o pokračování v implementační fázi a postupný přechod do udržovací fáze této úrovně na všech třech pilotních školách (Bradshaw et al., 2009). K ověření průběhu zavádění I. úrovně bude využit nástroj BoQ a bude vyhodnocen posun oproti výsledkům jeho administrace v předcházejícím školním roce.

Vzhledem ke značnému přetížení pedagogů i žáků ve školním roce 2020/21, k praktickému znemožnění fyzických návštěv školy spojených se sběrem dat a také předpokládanému zkreslení některých dat negativním působením distanční výuky a omezení sociálních kontaktů na psychiku dětí i sociální soudržnost tříd nebyla v rámci projektu provedena administrace BoQ ve druhém pololetí a neproběhlo plánované

10 Tř́́dní systémy zahrnují jak nácvik a vizualizaci očekávaného chování (kde školy hodnotily vyššśíspěšnost) tak konkretizovaná pozitivní zpětná vazba na vhodné chování v poměru 4:1 oproti konkretizované korekci nevhodného chování (cílem systému je zvýšit pozitivní zpětnou vazbu, ne cíleně snižovat korekce projevů nevhodného chování), systémy sběru dat a sledování výskytu náročného chování ve třídách a stanovení relevantních a předvídatelných reakcí na určité typy nevhodného chování (Kincaid,, Childs \& George, 2010) 
měření klimatu vybraných tříd. Namísto sběru dat byla školám poskytována metodická podpora v oblasti chování žáků, psychických obtíží, projevů ohrožení při online vzdělávání, podpory adaptace při návratu k prezenčnímu vyučování apod.

\section{Tabulky a obrázky}

Tab. 1 Vyhodnocení BoQ na třech pilotních základních školách

\begin{tabular}{|l|c|c|c|c|}
\hline KLÍČOVÁ KRITÉRIA & ZŠ 1 & ZŠ 2 & ZŠ 3 & PRŮMĚR \\
\hline Školní PBIS tým & $67 \%$ & $67 \%$ & $83 \%$ & $72 \%$ \\
\hline $\begin{array}{l}\text { Angažovanost pedagogic- } \\
\text { kého sboru }\end{array}$ & $33 \%$ & $33 \%$ & $50 \%$ & $39 \%$ \\
\hline $\begin{array}{l}\text { Efektivní postupy podpory } \\
\text { očekávaného chování }\end{array}$ & $0 \%$ & $25 \%$ & $0 \%$ & $8 \%$ \\
\hline $\begin{array}{l}\text { Vytvoření plánu sběru a } \\
\text { analýzy dat }\end{array}$ & $25 \%$ & $0 \%$ & $0 \%$ & $8 \%$ \\
\hline $\begin{array}{l}\text { Stanovení očekávaného } \\
\text { chování }\end{array}$ & $60 \%$ & $20 \%$ & $100 \%$ & $60 \%$ \\
\hline $\begin{array}{l}\text { Plán oceňování vhodného } \\
\text { chování }\end{array}$ & $14 \%$ & $0 \%$ & $0 \%$ & $5 \%$ \\
\hline $\begin{array}{l}\text { Plán výuky očekávaného } \\
\text { chování }\end{array}$ & $17 \%$ & $17 \%$ & $33 \%$ & $22 \%$ \\
\hline Plán implementace & $21 \%$ & $0 \%$ & $0 \%$ & $7 \%$ \\
\hline Třídní systémy & $0 \%$ & $10 \%$ & $20 \%$ & $10 \%$ \\
\hline Evaluace & $23 \%$ & $15 \%$ & $31 \%$ & $23 \%$ \\
\hline CELKEM V B0Q & & $71 \%$ & \\
\hline
\end{tabular}

\section{Diskuse}

Celoškolní zavedení trauma respektujícího přístupu s využitím implementačního rámce PBIS v České republice probíhá jako součást projektu Škola pomáhá ohroženým dětem. Postup implementace, ale také například změny klimatu vybraných tříd a další faktory budou dále výzkumně ověřovány, nicméně vzhledem k rozsahu a zaměření textu nebyly dále specifikovány. Rešerše zahraničních přístupů podporujících duševní zdraví dětí s následným výběrem PBIS a ověřením jeho efektivity při podpoře duševního zdraví žáků základních škol probíhá v rámci projektu financovaného Grantovou agenturou Univerzity Karlovy (projekt č. 1034419). Z dostupných pramenů a zahraničních výzkumů vyplývá, že je implementační rámec PBIS vhodným nástrojem pro komplexní péči o duševní zdraví všech dětí, přičemž současně umožňuje intenzivnější podporu dětem v riziku a individualizovanou podporu dětem s komplexními potřebami.

Implementace PBIS v prvním školním roce byla výrazně narušena pandemií COVID-19 a protiepidemickými opatřeními. Přesto pilotní školy zvládly zahajovací a částečně i implementační fázi celoškolního zavádění I. úrovně podpory PBIS díky př́ípravným konzultacím školního PBIS týmu s PBIS koučem na konci školního roku 2019/20 a proškolení pedagogického sboru v srpnu 2020. Implementace PBIS bude probíhat také ve školním roce 2021/22 a 2022/23, kdy budou adresována kritéria BoQ tak, aby byla naplňována celkově alespoň na 70 \%, což je hranice pro přechod do udržovací fáze I. úrovně podpory.

\section{Závěr}

Podporu duševního zdraví dětí je třeba zavádět plošně, především vzhledem k vysokému výskytu negativních zkušeností v dětství, které prokazatelně ovlivňují duševní i fyzické zdraví dětí. Vhodným místem pro dlouhodobou plošnou podporu duševního zdraví jsou základní školy a při využití implementačního rámce PBIS je navíc možné flexibilně zvyšovat intenzitu podpory chování a duševního zdraví dětí podle jejich aktuálních potřeb. Implementace PBIS probíhá v České republice na třech základních školách, ve kterých byla v prvním roce zavedena I. úroveň PBIS pouze částečně vzhledem k pandemické situaci. Implementace PBIS a další sběr dat bude probíhat také ve školním roce 2021/22 a 2022/23. 


\section{Literatura}

Bradshaw, C. P. (2013). Preventing bullying through positive behavioral interventions and supports (PBIS): A multitiered approach to prevention and integration. Theory Into Practice, 52(4), 288-295.

Bradshaw, C. P., W. M. Reinke, L. D. Brown, K. B. Bevans \& P. J. Leaf (2008). Implementation of School-Wide Positive Behavioral Interventions and Supports (PBIS) in Elementary Schools: Observations from a Randomized Trial. Education and Treatment of Children [online]. 31(1), 1-26 [cit. 2021-09-20]. D0I: 10.1353/etc.0.0025. ISSN 1934-8924.

Bradshaw, C. P., Debnam, K., Koth, C. W., \& Leaf, P. (2009). Preliminary Validation of the Implementation Phases Inventory for Assessing Fidelity of Schoolwide Positive Behavior Supports [Online]. Journal Of Positive Behavior Interventions, 11(3), 145-160. https://doi.org/10.1177/1098300708319126

Brant, J., Nováková, J., Tupý, J. (2004): Domácí vzdělávání v České republice ve školním roce 2003/2004. Průběžná zpráva o stavu PODV, VÚP 2004

Clunies-Ross, P., Little, E., \& Kienhuis, M. (2008). Self-reported and actual use of proactive and reactive classroom management strategies and their relationship with teacher stress and student behaviour. Educational Psychology, 28, 693-710

Cohen, R., Kincaid, D., \& Childs, K. E. (2007). Measuring school-wide positive behavior support implementation: Development and validation of the benchmarks of quality. Journal of Positive Behavior Interventions, 9(4), 203-213.

Cole, S., A. Eisner, M. Gregory \& J. Ristuccia. (2013). Helping traumatized children learn: Creating and Advocating for Trazuma-Sensitive Schools [online]. 2. Boston, MA: Massachusetts Advocates for Children [cit. 2021-09-08].

Colvin, G. \& G. M. Sugai. (2018). 7 steps for developing a proactive schoolwide discipline plan: a guide for principals and leadership teams. Second Edition. Thousand Oaks, California: Corwin, A SAGE Company. ISBN 978-150-6328-195

Cronholm, P. F., Forke, C. M., Wade, R., Bair-Merritt, M. H., Davis, M., Harkins-Schwarz,

M., Pachter, L. M., \& Fein, J. A. (2015). Adverse childhood experiences: Expanding the concept of adversity. American Journal of Preventive Medicine, 49(3), 354-361.

ČOSIV. (2020). 0 projektu [Online]. Retrieved September 22, 2021, from https://www.pbiscr.cz/ cs/2020/10/09/0-projektu/

ČOSIV. (2021). První rok s PBIS [Online]. Retrieved September 22, 2021, from https://www.pbiscr.cz/ cs/2021/07/30/prvni-rok-s-pbis/

Dotson Davis, L. (2019). Implications of trauma-sensitive practices at the middle level. Middle Grades Review, $5(1), 3$.

Eber, L., Barrett, S., Scheel, N., Flammini, A., \& Pohlman, K. (2020). Integrating a Trauma-Informed Approach within a PBIS Framework. Technical Assistance Center on Positive Behavioral Interventions and Supports.

Felitti, V. J., Anda, R. F., Nordenberg, D., Williamson, D. F., Spitz, A. M., Edwards, V., Koss, M. P., \& Marks, J. S. (1998). Relationship of childhood abuse and household dysfunction to many of the leading causes of death in adults: The adverse childhood experiences (ACE) study. American Journal of Preventive Medicine, 14(4), 245-258. https://doi.org/10.1016/s0749-3797(98)00017-8.

Gerrity, E., \& Folcarelli, C. (2008). Child traumatic stress: What every policymaker should know [Online] (1st ed.). Los Angeles. National Center for Child Traumatic Stress.

Honsinger, C., \& Brown, M. H. (2019). Preparing Trauma-Sensitive Teachers: Strategies for Teacher Educators. Teacher Educators' Journal, 12, 129-152.

Horner, R. H., G. M. Sugai \& C. M. Anderson (2017). Focus on Exceptional Children [online]. 42(8) [cit. 202109-17]. DOI: 10.17161/fec.v42i8.6906. ISSN 0015-511X. https://journals.ku.edu/FOEC/article/ view/6906

Jones, W., J. Berg \& D. Osher. (2018). Trauma and Learning Policy Initiative (TLPI): Trauma-Sensitive Schools Descriptive Study [online]. Washington: American Institutes for Research, [cit. 2021-09-10]. https://traumasensitiveschools.org/wp-content/uploads/2019/02/TLPI-Final-Report_Full-Report-002-2-1.pdfs

Keating, W. L. (2016). Teacher satisfaction regarding the use of positive behavior intervention support (PBIS) in schools. Seattle University. ProQuest Dissertations Publishing. 10167993. 
Kincaid, D., Childs, K., \& George, H. (2010). School-wide Benchmarks of Quality: Scoring Form (Revised). Unpublished Instrument.

Larkin, H., J. J. Shields \& R. F. Anda. (2012). The Health and Social Consequences of Adverse Childhood Experiences (ACE) Across the Lifespan: An Introduction to Prevention and Intervention in the Community [online]. 40(4), 263-270 [cit. 2021-09-17]. DOI: 10.1080/10852352.2012.707439. ISSN 1085-2352. http://www.tandfonline.com/doi/abs/10.1080/10852352.2012.707439

Latham, G. (1988). The birth and death cycles of educational innovations. Principal, 68(1), 41-43.

Merrick, M. T., D. C. Ford, K. A. Ports \& A. S. Guinn. (2018). Prevalence of Adverse Childhood Experiences From the 2011-2014 Behavioral Risk Factor Surveillance System in 23 States. JAMA Pediatrics [online]. 172(11) [cit. 2021-09-20]. D0I: 10.1001/jamapediatrics.2018.2537. ISSN 2168-6203. http://archpedi.jamanetwork.com/article.aspx?doi=10.1001/jamapediatrics.2018.2537

Nelen, M. J. M., Willemse, T. M., van Oudheusden, M. A., \& Goei, S. L. (2020). Cultural Challenges in Adapting SWPBIS to a Dutch Context [Online]. Journal Of Positive Behavior Interventions, 22(2), 105-115. https://doi.org/10.1177/1098300719876096

Nurius, P. S., Logan-Greene, P., \& Green, S. (2012). Adverse Childhood Experiences (ACE) Within a Social Disadvantage Framework: Distinguishing Unique, Cumulative, and Moderated Contributions to Adult Mental Health [Online], 40(4), 278-290. https://doi.org/10.1080/10852352.2012.707443

OECD. (2018). Education at a Glance 2018: OECD Indicators, [Online] (1st ed.). Paris: OECD Publishing.

Perry, B. D., Pollard, R. A., Blakley, T. L., Baker, W. L., \& Vigilante, D. (1995). Childhood trauma, the neurobiology of adaptation, and "use-dependent" development of the brain: How "states" become "traits". Infant mental health journal, 16(4), 271-291.

Rawson, S. (2020). Applying Trauma-Sensitive Practices in School Counseling: Interventions for Achieving Change (1st ed.). Routledge. https://doi.org/10.4324/9780429281402

Response To Intervention (2013). Special Education Guide [online]. Washington: Degree Prospects. [cit. 2021-09-21].

Simonsen, B., \& Sugai, G. (2013). PBIS in alternative education settings: Positive support for youth with high-risk behavior. Education and Treatment of Children, 3-14.

Sciaraffa, M. A., Zeanah, P. D., \& Zeanah, C. H. (2018). Understanding and Promoting Resilience in the Context of Adverse Childhood Experiences [Online]. Early Childhood Education Journal, 46(3), 343353. https://doi.org/10.1007/s10643-017-0869-3

Velemínský, M., Rost M., Samková J., Samek j., Sethi A. D. (2017). Studie negativních zážitků z dětství (ACE) v České republice. Česko-slovenská pediatrie: časopis České a Slovenské pediatrické společnosti. Praha: Práce, 72(7), 409-420. ISSN 0069-2328.

\section{Informace o autorech \\ Mgr. Anna Kubíčková}

V rámci doktorského studia realizuje projekt s názvem Speciálně pedagogická intervence v komplexní péči o duševní zdraví dětí. V roce 2019 absolvovala proškolení v implementaci PBIS v Illinois (USA). V současné době působí v ČOSIV, z. s. jako koordinátorka projektu Škola pomáhá ohroženým dětem pilotujícího PBIS na třech ZŠ. Dále je členkou pracovní skupiny wellbeingu ve vzdělávání projektu Partnerství 2030+ a aktivně působí na katedře speciální pedagogiky PedF UK.

Telefon: +420 731483081

Email: anna.kubickova@cosiv.cz

URL: www.pbiscr.cz

\section{PhDr. Lenka Felcmanová, Ph.D.}

Je místopředsedkyní České odborné společnosti pro inkluzivní vzdělávání (ČOSIV) a působí na Katedře speciální pedagogiky PedF UK. V minulosti působila na MŠMT v Sekci rovných př́ležitostí ve vzdělávání. V ČOSIV se věnuje zavádění výzkumně ověřených přístupů v oblasti managementu chování žáků ve školách a podpory vzdělávání dětí s vývojovým traumatem. Je vedoucí pracovní skupiny věnující se systémovému uchopení podpory wellbeingu ve vzdělávání v rámci projektu Partnerství pro vzdělávání 2030+.

URL: www.cosiv.cz 